ORIGINAL ARTICLE

\title{
Epidermal growth factor regulates Mcl-1 expression through the MAPK-Elk-1 signalling pathway contributing to cell survival in breast cancer
}

\author{
EP Booy ${ }^{1,2}$, ES Henson $^{1,2}$ and SB Gibson ${ }^{1,2}$ \\ ${ }^{1}$ Department of Biochemistry and Medical Genetics, University of Manitoba, Winnipeg, Manitoba, Canada and ${ }^{2}$ Manitoba Institute \\ of Cell Biology, University of Manitoba, Winnipeg, Manitoba, Canada
}

\begin{abstract}
Myeloid cell leukaemia-1 (Mcl-1) is an anti-apoptotic member of the Bcl-2 family that is elevated in a variety of tumour types including breast cancer. In breast tumours, increased Mcl-1 expression correlates with high tumour grade and poor patient survival. We have previously demonstrated that Her-2 levels correspond to increased Mcl-1 expression in breast tumours. Epidermal growth factor (EGF) receptor signalling is frequently deregulated in breast cancer and leads to increased proliferation and survival. Herein, we determined the critical downstream signals responsible for the EGF mediated increase of Mcl-1 and their role in cell survival. We found that both Mcl-1 mRNA and protein levels are rapidly induced upon stimulation with EGF. Promoter analysis revealed that an Elk-1 transcription factor-binding site is critical for EGF activation of the Mcl-1 promoter. Furthermore, we found that knockdown of Elk-1or inhibition of the Erk signalling pathway was sufficient to block EGF upregulation of Mcl-1 and EGF mediated cell survival. Using chromatin immunoprecipitation and biotin labelled probes of the Mcl-1 promoter, we found that Elk-1 and serum response factor are bound to the promoter after EGF stimulation. To determine whether Mcl-1 confers a survival advantage, we found that knockdown of Mcl-1 expression increased apoptosis whereas overexpression of Mcl-1 inhibited drug induced cell death. In human breast tumours, we found a correlation between phosphorylated Elk-1 and Mcl-1 protein levels. These results indicate that the EGF induced activation of Elk-1 is an important mediator of Mcl-1 expression and cell survival and therefore a potential therapeutic target in breast cancer.
\end{abstract}

Oncogene (2011) 30, 2367-2378; doi:10.1038/onc.2010.616; published online 24 January 2011

Keywords: Mcl-1; Elk-1; breast cancer; regulation; drug resistance

\section{Introduction}

Myeloid cell leukaemia-1 (Mcl-1) is an anti-apoptotic member of the Bcl-2 family of proteins that has a critical role in regulating the balance between survival and death signals (Yip and Reed, 2008). Anti-apoptotic Bcl2 family members are frequently deregulated in human cancers and Mcl-1 is elevated in a variety of tumour types (Backus et al., 2001; Zhang et al., 2002; Song et al., 2005) including breast cancer, where it has been found to correlate with poor prognosis (Ding et al., 2007). Small molecule inhibitors targeting pro-survival Bcl-2 family members are currently in clinical trials (Vogler et al., 2009); however, due to inherent low affinities for Mcl-1, Mcl-1 overexpression was frequently found to mediate resistance (Oltersdorf et al., 2005; van Delft et al., 2006; Lin et al., 2007; Tse et al., 2008). More recently developed small molecule inhibitors that have a higher ability to disrupt Mcl-1 function have overcome resistance to other pan-Bcl-2 family inhibitors (Nguyen et al., 2007). This demonstrates the importance of Mcl-1 in the regulation of apoptosis.

The epidermal growth factor (EGF) receptor family is composed of four key membrane spanning receptors referred to as ErbB1-4 (Her-1-4). Of these receptors, ErbB1 (Her-1) and ErbB2 (Her-2) are most frequently overexpressed in human cancers (Klapper et al., 2000). In breast cancer, ErbB2 (Her-2) is overexpressed in roughly $20 \%$ of cases and correlates with poor prognosis (Singleton and Strickler 1992; Nanda 2007). Mcl-1 has previously been described in the literature as a downstream target of the EGF signalling pathway in oesophageal (Leu et al., 2000), colorectal (SchulzeBergkamen et al., 2008) and lung (Song et al., 2005) cancer cell lines. We have evidence that suggests a similar response is seen in breast cancer and have found a correlation between Her-2 positive breast cancers and high levels of Mcl-1 expression (Henson et al., 2006). Although one report has demonstrated a correlation between phosphorylated Stat-3 and elevated Mcl-1 in breast tumours (Hsieh et al., 2005), the transcriptional mechanisms governing $\mathrm{Mcl}-1$ expression in breast cancer have not been thoroughly investigated.

A number of studies exist describing the transcriptional regulation of the $\mathrm{Mcl}-1$ gene in a diverse set of cell types. The Mek/Erk pathway has been implicated to
Correspondence: Dr SB Gibson, Manitoba Institute of Cell Biology, University of Manitoba, 675 McDermot Ave, Winnipeg, Manitoba, Canada R3E 0V9.

E-mail: gibsonsb@cc.umanitoba.ca

Received 23 August 2010; revised 6 December 2010; accepted 14 December 2010; published online 24 January 2011 
govern Mcl-1 transcription in several cell line models (Boucher et al., 2000; Leu et al., 2000; Schubert and Duronio 2001). Two independent studies have demonstrated that Elk-1 and serum response factor (SRF), downstream of Erk activation, contribute to basal Mcl-1 expression levels as well as induction of transcription by treatment with 12-O-tetradecanoylphorbol-13-acetate in HEK 293, HeLa and M1-1 cell lines (Townsend et al., 1999; Vickers et al., 2004). In other cell types, the PI3K/ AKT pathway has been described as critical for Mcl-1 regulation (Wang et al., 1999; Kuo et al., 2001; Longo et al., 2008). Additionally, the transcription factor Stat-3 has been tied to Mcl-1 expression in cells of hematopoietic origin (Puthier et al., 1999; Liu et al., 2003). The precise signalling and transcriptional mechanisms regulating Mcl-1 in breast cancer cells remains unclear.

Herein, we determined that Erk activation of the transcription factor Elk-1 is critical for transcriptional regulation of $\mathrm{Mcl}-1$ following EGF treatment and also has a significant role in EGF mediated cell survival in breast cancer.

\section{Results}

Stimulation of the EGF signalling pathway upregulates Mcl-1 protein and $m R N A$ levels

Several studies have suggested that EGF signalling regulates transcription of Mcl-1 (Leu et al., 2000; Cetin et al., 2010). We have previously found a correlation between elevated Her-2 and Mcl-1 levels in breast tumours (Henson et al., 2006). To further assess whether Mcl-1 expression is modified by EGF receptor activation in breast cancer, we studied $\mathrm{Mcl}-1$ protein and mRNA levels in MCF-7 and SK-BR-3 breast cancer cell lines following treatment with EGF. As shown in
Figure 1a, both MCF-7 and SK-BR-3 cells demonstrated a marked elevation of Mcl-1 protein levels within $2 \mathrm{~h}$ of treatment and protein levels remained elevated after $8 \mathrm{~h}$ of treatment. As Mcl-1 has a short half-life (Akgul et al., 2000), rapid fluctuations in protein levels can occur in the absence of a change in relative transcription of the $M c l-1$ gene. Therefore it was necessary to determine whether the observed changes were a result of elevated transcription or modification of protein stability. Mcl-1 mRNA levels were detected over a 120 min time course following stimulation with EGF by semi-quantitative real-time PCR. After $30 \mathrm{~min}$ of EGF treatment, the Mcl-1 mRNA level was increased by fourfold in MCF-7 cells and at $60 \mathrm{~min}$ EGF treatment in SK-BR-3 cells the mRNA level had increased nearly threefold. The mRNA levels peaked after $90 \mathrm{~min}$ of EGF stimulation at a 12-fold increase in MCF-7 cells and fourfold increase in SK-BR-3 cells. Control treated cells failed to demonstrate an increase in Mcl-1 mRNA levels over the same time course (dashed line, Figure 1b). This strongly suggests that EGF signalling elevates transcription of the $\mathrm{Mcl}-1$ gene in breast cancer cells.

A small region of the $M c l-1$ promoter containing a serum response element is necessary for EGF induced transcription

We set out to identify the key regulatory elements necessary for EGF induced transcription of Mcl-1 in a breast cancer cell line model. To determine the critical region of the Mcl-1 promoter, a $3974 \mathrm{bp}$ fragment upstream of the translation start site was amplified by PCR and cloned into the PGL-3 luciferase reporter vector. A series of deletion mutants were generated to narrow down the region of interest. A small segment of
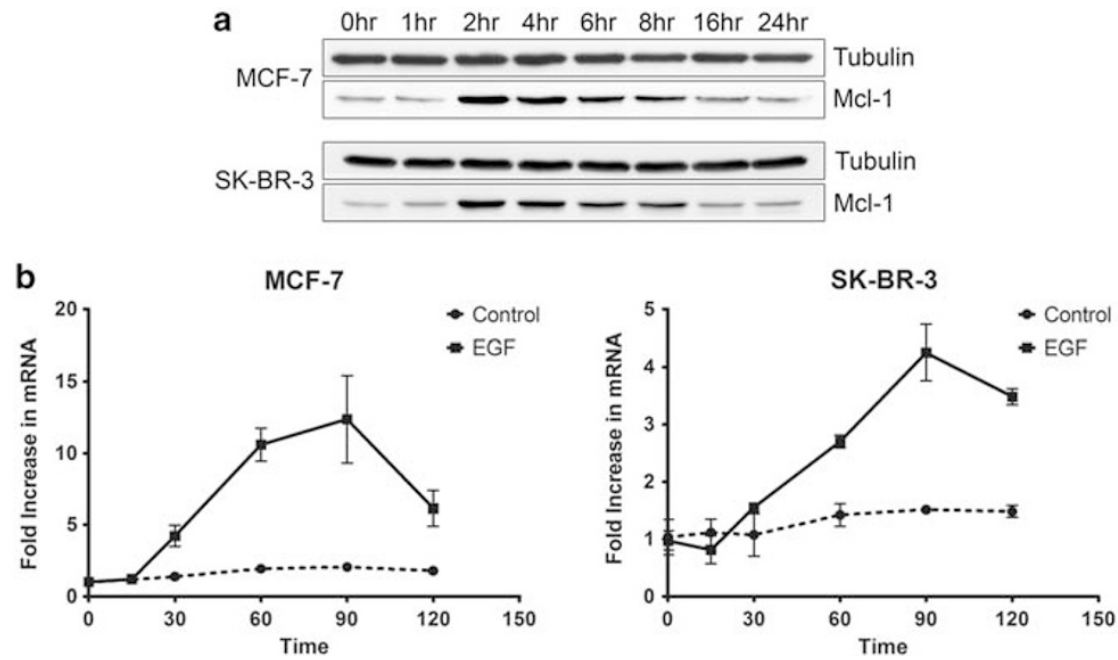

Figure 1 Stimulation of the EGF pathway elevates Mcl-1 protein and mRNA levels. (a) Western blot time course following addition of $1 \mu \mathrm{g} / \mathrm{ml} \mathrm{EGF}$ to the cell culture media. Cells were serum starved for $24 \mathrm{~h}$ before treatment with EGF. Blots were re-probed with antitubulin antibodies as a loading control. (b) Real-time PCR analysis of Mcl-1 transcript levels following stimulation with EGF. In all $100 \mathrm{ng}$ template RNA was amplified with primers specific to Mcl-1. Results were standardized using primers to the housekeeping gene cyclophilin. Results are expressed as a fold change relative to the basal levels observed in the unstimulated control sample. Data represents the mean of three experiments \pm the s.d. 
the promoter, $\sim 300$ bp upstream of the translation start site, was found to be sufficient for both basal and EGF induced expression of the luciferase reporter in $\mathrm{MCF}-7$ cells (Figure 2a). Sequence alignment of the human and mouse Mcl-1 promoters showed a region of high identity within this fragment (Figure 2b). A series of $7 \mathrm{bp}$ deletions were created within the $4 \mathrm{~kb}$ promoter reporter construct to identify potentially important cisacting DNA elements. Specifically, high scoring putative transcription factor binding sites and the region of high identity with the mouse Mcl-1 promoter were targeted for deletion (Figure 2b). Transcription factor binding sites were identified using the TFSearch software (Heinemeyer et al., 1998). We found that deletion of two regions corresponding to a potential Elk-1 binding site (Del. 3) and SRF CarG box (Del. 6 and Del. 7) reduced EGF activation of the Mcl-1 promoter (Figure 2c). Both of these sites were within the region of high identity between the human and mouse promoters (Figure 2b). Additional transcription factor binding sites including an ATF2 consensus site (Del. 1) and putative nuclear factor $(\mathrm{NF})-\kappa \mathrm{B}$ binding sites (data not shown) were deleted, but failed to significantly alter Mcl-1 promoter activity. The full-length Mcl-1 promoter (-3974) was used as a positive control. Similar results were obtained with SK-BR-3 cells (Supplementary Figure $1 \mathrm{~A}$ and $\mathrm{B}$ ).

\section{Elk-1 is activated by stimulation with EGF and is essential for control of Mcl-1 protein levels}

The Mek/Erk pathway is activated by EGF and has been shown to activate the transcription factor Elk-1 (Yordy and Muise-Helmericks, 2000). To determine whether EGF stimulation resulted in activation of Erk1/ 2 and Elk-1, MCF-7 and SK-BR-3 cells were treated with EGF over a $60 \mathrm{~min}$ time course. As shown in Figure 3a, Erk1/2 were phosphorylated within 5 min and phosphorylation decreased after $60 \mathrm{~min}$ of EGF treatment. Following similar kinetics, phosphorylation of Elk-1 at Ser383 was detected at 5 min following EGF treatment and decreased by $60 \mathrm{~min}$. After $60 \mathrm{~min}$, an
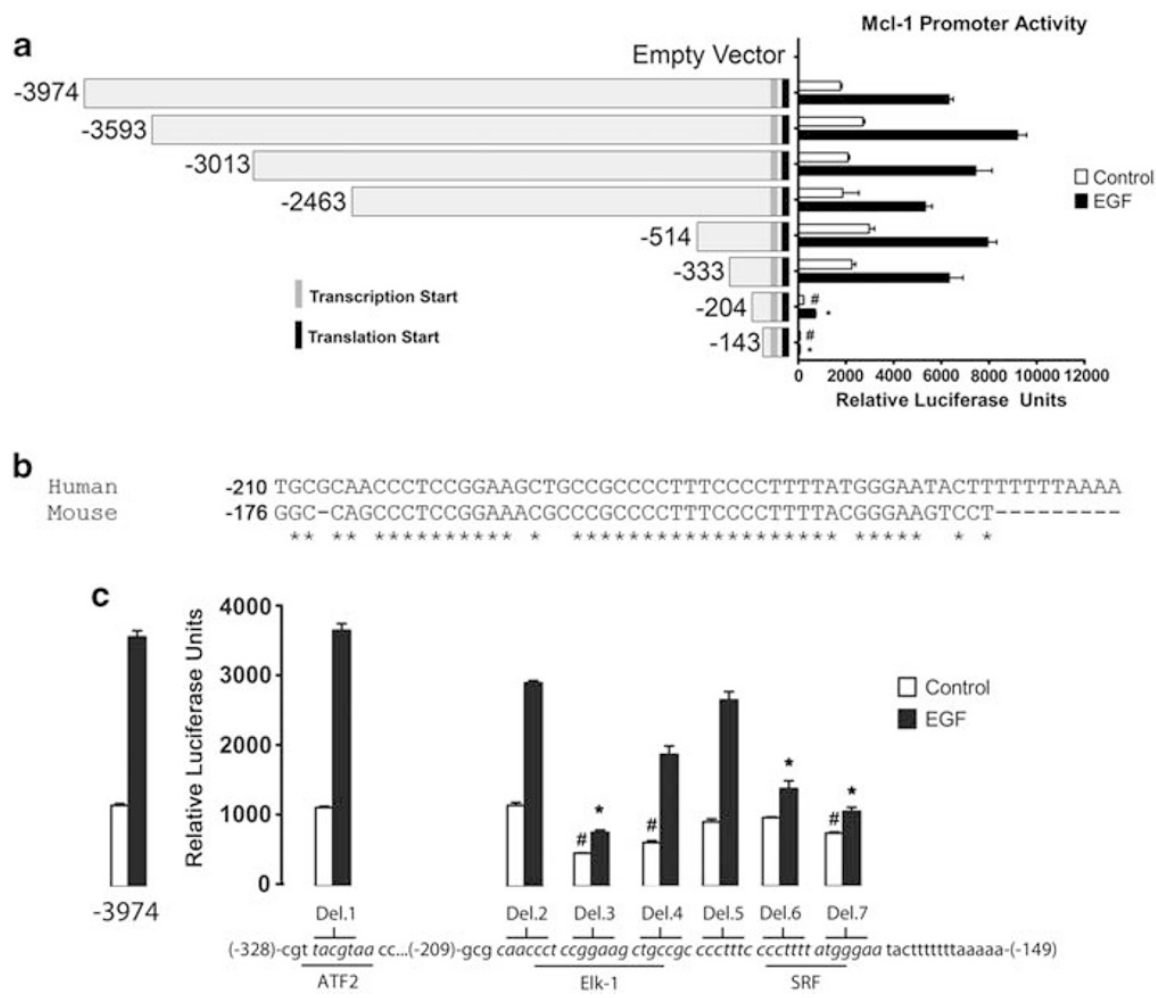

Figure 2 A small region of the Mcl-1 promoter containing a serum response element is necessary for EGF induced transcription. (a) Luciferase assay demonstrating activity of eight deletion mutants of the Mcl-1 promoter in MCF-7 cells. Promoter inserts cloned into the PGL3 vector are shown to scale to the left of the axis. Sequence length upstream from translation start site is indicated for each construct. Basal and EGF induced promoter activity is shown as relative luciferase units. Data represent the mean of three independent experiments \pm s.d.. Constructs -204 and -143 were the only deletions to show highly significant reduction in activity ( $\#$ indicates $P=<0.005$ compared with control -3974 , *indicates $P=<0.005$ compared with EGF treated -3974$)$. Nearly identical results were observed with the SK-BR-3 cell line (Supplementary Figure 1). Results were standardized by $\beta$-gal co-transfection. (b) A sequence alignment of the human and mouse Mcl-1 $5^{\prime}$ promoter region revealed an area of high identity near the translation start site. Distance upstream from translation start is indicated at the $5^{\prime}$ end of each sequence. (c) The 7 bp deletions were introduced into the 3974 bp promoter construct and the impact on promoter activity is shown compared with the unmutated 3974 bp fragment (bars to left of axis). Deletions 3 and 7 demonstrated the strongest reduction in basal and EGF induced activity. Data are shown in the context of the Mcl-1 promoter sequence with predicted transcription factor binding sites indicated below the sequence. Deletions are separated by spaces and bases deleted are indicated by italics. 
increase in Mcl-1 protein was detected in MCF-7 cells. Control treatment failed to induce phosphorylation of these proteins over the same time course. Similar results were observed in SK-BR-3 cells (Figure 3a). Pretreatment with U0126, a highly specific inhibitor of Mek1/2 (Favata et al., 1998) prevented both Erk1/2 and Elk-1 phosphorylation in MCF-7 and SK-BR-3 cells. This inhibition also prevented the elevation of Mcl-1 protein levels following EGF treatment (Figure 3b). The Erk inhibitor 3-(2-aminoethyl)-5-((4-ethoxyphenyl)methylene)-2,4-thiazolidinedione, previously published to prevent Elk-1 phosphorylation at Ser383 (Chen et al., 2006), also produced similar results (Figure 6c). Targeted knockdown of Elk-1 expression by transfection of a specific small interfering (si)RNA reduced both basal and EGF induced Mcl-1 levels substantially in both cell lines (Figure 3c). Knockdown of two other transcription factors, Stat-3 and NF- $\kappa \mathrm{B}$, failed to have an effect on basal or EGF induced levels of Mcl-1 (Supplementary Figure 2A). Unexpectedly, knockdown of SRF had no impact on basal or EGF induced Mcl-1 protein or mRNA levels (Supplementary Figure 2A/B). This data confirms the importance of
Elk-1in transcriptional regulation of Mcl-1 in breast cancer cells.

\section{Elk-1 and SRF bind to the Mcl-1 promoter}

To assess whether the transcription factors Elk-1 and SRF bind to the Mcl-1 promoter, a chromatin immunoprecipitation (ChIP) experiment was performed with MCF-7 cells using primers that amplify a $163 \mathrm{bp}$ region containing the putative Elk-1 and SRF binding sites identified in Figure 2c. ChIP was performed with Elk-1 and SRF antibodies along with two negative antibody controls and a no antibody control (beads alone). Elk-1 was detectable on the Mcl-1 promoter by ChIP before stimulation with EGF (Figures 4a and b). Under unstimulated conditions, SRF was only marginally detectable on the Mcl-1 promoter; however, within 10 min of adding EGF there was a significant elevation (85-fold enrichment) of SRF at the promoter, which was maintained after $30 \mathrm{~min}$ of stimulation (Figures 4a and $b$ ). This was followed by an elevation of Elk-1 at the 20 and $30 \mathrm{~min}$ time points. Isotype controls (ctrl 1 is an antibody against NF- $\kappa \mathrm{B}, \operatorname{ctrl} 2$ is an antibody against a
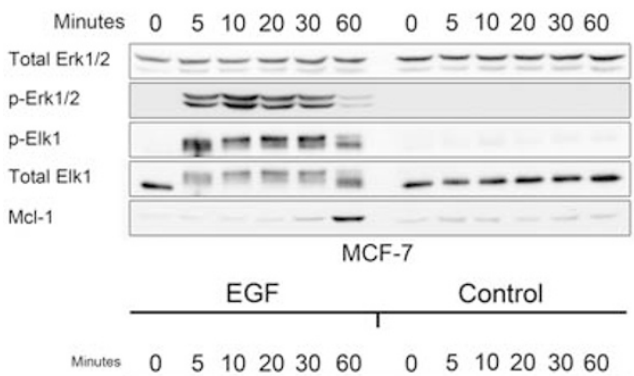

Total Erk1/2 $= \pm= \pm= \pm= \pm=$ p-Erk1/2

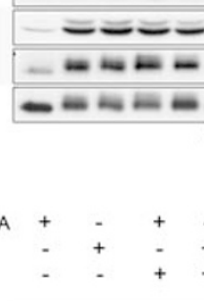

p-Elk1

Total Elk1

-

SK-BR-3

C

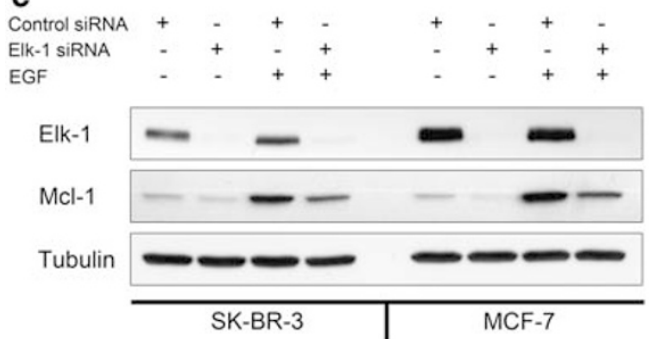

b
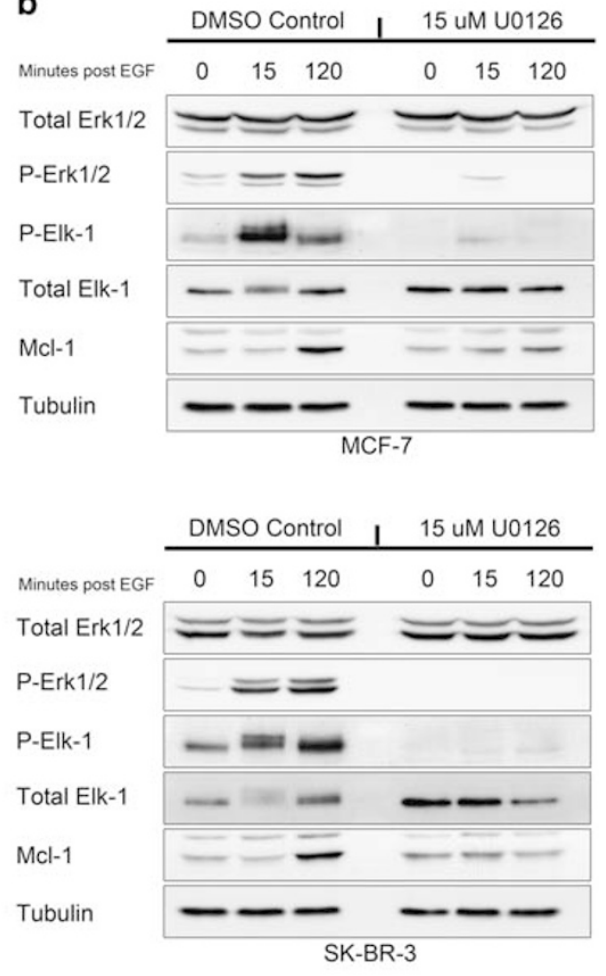

Figure 3 Elk-1 is activated by stimulation with EGF and is essential for control of Mcl-1 protein levels. (a) Cells were serum starved for $24 \mathrm{~h}$ and then EGF was added to the cell culture media at a concentration of $1 \mu \mathrm{g} / \mathrm{ml}$ for a $60 \mathrm{~min}$ time course. An equal volume of the EGF solvent was used as a control. Erk1/2 activation was assessed by antibodies specific for Erk $1 / 2$ only when dually phosphorylated at Thr202 and Tyr204. Activation of Elk-1 was detected with an antibody specific to Elk-1 only when phosphorylated at Ser383. Blots were re-probed for total Erk1/2 and Elk-1 to control for loading. Increase in Mcl-1 is shown for MCF-7 cells. (b) Cells were pre-treated with the Mek inhibitor U0126 or an equal volume of dimethyl sulfoxide for 20 min before stimulation with EGF. Lysates were taken at 15 and 20 min post stimulation and blots were probed with the same antibodies as in (a). (c) In all 30 pmol siRNA specific for Elk-1 or a scrambled control was transfected into SK-BR-3 and MCF-7 cells by nucleofection. Twenty-four hour after transfection, the cells were starved for a subsequent $24 \mathrm{~h}$ followed by stimulation with EGF or control for $2 \mathrm{~h}$. 
a

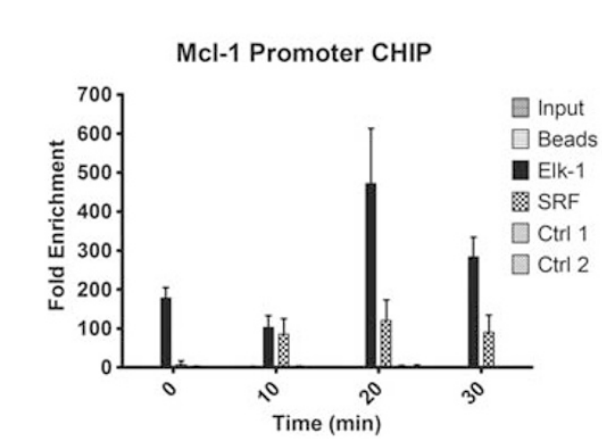

b

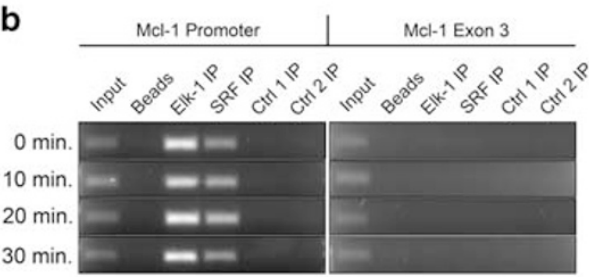

C

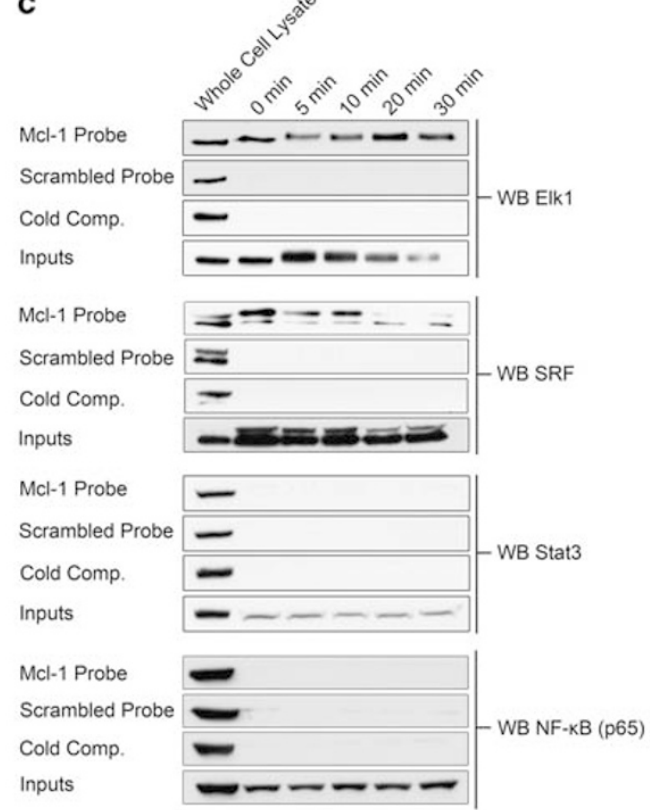

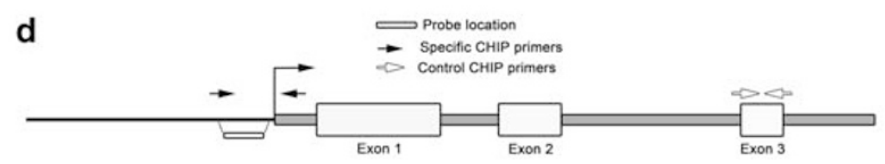

Figure 4 The transcription factors Elk-1 and SRF bind to the Mcl-1 promoter in MCF-7 cells. (a) Chromatin immunoprecipitation using antibodies specific to Elk-1 and SRF was performed as described in Material and methods section. Controls shown are two negative antibody controls as well as a no antibody control (protein G beads alone). Ctrl1 is an antibody against Stat-3 and Ctrl 2 is an

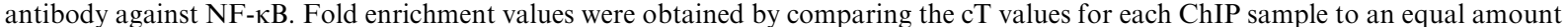
of input DNA. Primers were designed in the last exon of the $\mathrm{Mcl}-1$ gene to demonstrate specificity (RT-PCR data not shown, PCR products shown in (b)). Data represents the mean of three independent experiments \pm standard error. (b) PCR products were run on an agarose gel following each ChIP experiment to assess reaction specificity. (c) Streptavidin pull-down assay to detect transcription factor binding to a $50 \mathrm{bp}$ double-stranded biotin labelled probe specific to the Mcl-1 promoter region of interest. Cells were stimulated with EGF for different time periods and nuclear extracts incubated with the Mcl-1 probe. Following pull down with streptavidin beads, the bound proteins were detected by SDS/polyacrylamide gel electrophoresis and western blotting. To control for specificity, a biotinlabelled scrambled probe was used along with competition with an unlabelled specific probe. Blots were probed with antibodies to the transcription factors Stat-3 and NF- $\mathrm{kB}$ to demonstrate binding specificity. (d) Schematic representation of the $M c l-1$ gene showing approximate locations of the biotin labelled probe used for the Streptavidin pull down as well as the primers used for ChIP.

Stat-3) failed to immunoprecipitate Mcl-1 promoter fragments and demonstrated fold enrichment values close to zero (Figures $4 \mathrm{a}$ and $\mathrm{b}$ ). All of the antibodies failed to enrich a region of the third exon of the $\mathrm{Mcl}-1$ gene (Figure $4 b$ ).

Further validation that Elk-1 and SRF bind to the region of interest was obtained by performing a streptavidin pull-down assay using a biotin-labelled $50 \mathrm{bp}$ probe complementary to the region of interest (155-205 bp upstream of translation start). The Mcl-1 promoter specific probe was able to pull down both Elk1 and SRF from EGF treated nuclear lysates (Figure $4 \mathrm{c}$ ). The scrambled probe did not demonstrate observable binding and the presence of an excess of unlabelled probe successfully competed away the signal for both Elk-1 and SRF. Binding specificity was determined by using antibodies against two other transcription factors, NF- $\mathrm{KB}$ and Stat-3 (Figure 4c). The decrease in SRF binding observed following stimulation in the pull-down assay may be due to increased recruitment of SRF to the chromatin and therefore reduced availability of the protein in the assay.

\section{Both EGF treatment and modulation of Mcl-1 expression impact the survival of $S K-B R-3$ cells}

It has been established that EGF receptor activation elevates survival and resistance to apoptosis (Klapper et al., 2000). In Figure 5a, we confirmed that treatment of SK-BR-3 cells with EGF significantly reduced the levels of apoptosis induced by both etoposide and doxorubicin treatment. Protection was most evident at low drug concentrations wherein EGF reduced $5 \mu \mathrm{M}$ etoposide induced cell death from 42 to $21 \%$ and $0.5 \mu \mathrm{M}$ doxorubicin induced cell death from 32 to $12 \%$. To assess the contribution of Mcl-1 to the survival of breast cancer cells we performed a targeted knockdown experiment with Mcl-1 specific small interfering (si)RNA. Twenty-four hours following siRNA transfection there was a substantially higher number of apoptotic 

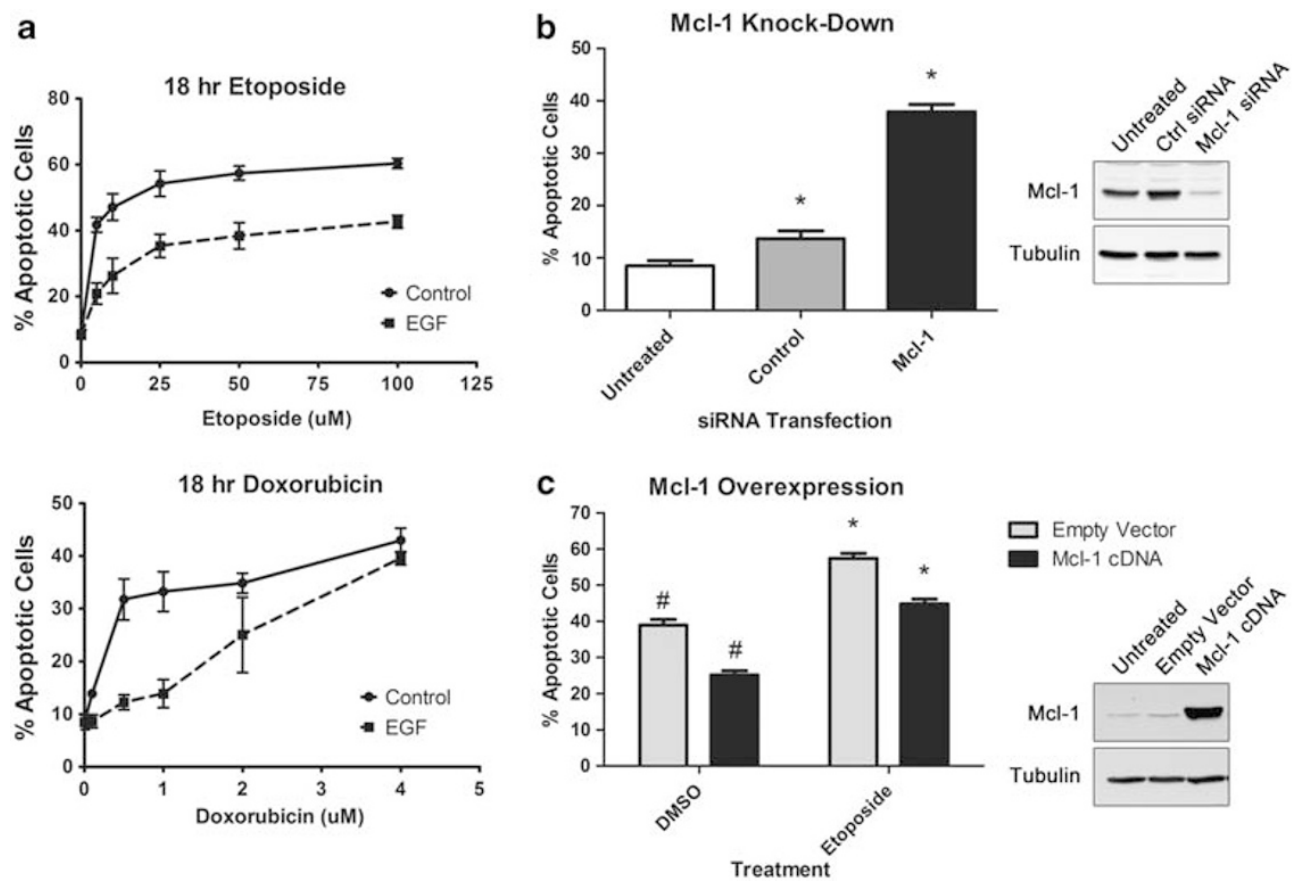

Figure 5 Both EGF treatment and modulation of Mcl-1 expression impacts the survival of SK-BR-3 cells. (a) SK-BR-3 cells were pretreated $1 \mathrm{hr}$ with EGF or control and then treated with etoposide or doxorubicin at increasing concentrations for $18 \mathrm{~h}$. Apoptosis was assessed by analysis of the sub-G1 peak by flow cytometry. Data represents three independent experiments \pm standard error. (b) SKBR-3 cells were transfected with 30 pmol control siRNA or siRNA specific to Mcl-1. Knockdown was verified by western blotting. Apoptosis was assessed $24 \mathrm{~h}$ post transfection (*indicates $P<0.05$ ). (c) Mcl-1 overexpression protects SK-BR-3 cells from drug induced apoptosis. Cells were transfected with pCDNA3-Mcl-1 or empty vector $24 \mathrm{~h}$ before treatment with $5 \mu \mathrm{m}$ etoposide. Cell death was measured $18 \mathrm{~h}$ later by sub-G1 analysis. Results are the mean of three independent experiments \pm s.d. ("Indicates $P<0.05$ comparing control cells, * indicates $P<0.05$ comparing etoposide treated cells.) Please note the Mcl-1 expression levels following overexpression or knockdown were detected at different exposure times and do not reflect relative expression levels.

cells (38\%) with Mcl-1 knockdown as compared with untreated cells $(9 \%)$ or transfection with a scrambled control siRNA (12\%, Figure 5b). This implies that a minimal level of Mcl-1 expression is critical for cell survival in breast cancer cell lines. Overexpression of Mcl-1 by transfection of the Mcl-1 complementary DNA resulted in resistance to transfection toxicity $(25 \%)$ and etoposide $(45 \%)$ induced cell death as compared with the empty vector (40 and 55\%, respectively, Figure 4c). These results demonstrate that Mcl-1 has an important role in cell survival.

\section{EGF protects breast cancer cells from apoptosis through a mechanism that relies on signalling via the Mek/Erk pathway}

As Mcl-1 knockdown alone was sufficient to induce apoptosis, we determined whether prevention of Mcl-1 upregulation would reverse the protective effects conferred by EGF pre-treatment. The Mek inhibitor U0126 completely prevents EGF induced upregulation of Mcl-1 protein levels (Figure 6a) and also results in a significant reduction of the protective effect of EGF (Figure 6b). In both the control and U0126 treated cells, etoposide induced nearly identical levels of apoptosis (39.4\% in control and $41.4 \%$ in the U0126 pre-treated cells). Pre-treatment with EGF resulted in a reduction in the amount of apoptosis induced by etoposide from 39 to $19 \%$. When the cells were also pre-treated with U0126 the EGF treatment only resulted in a reduction from 41 to $31 \%$ (Figure $6 b$ ).

To verify the result with U0126, the experiment was repeated using an Erk1/2 inhibitor (Figures 6c and d). The Erk1/2 inhibitor alone displayed slight toxicity that appeared to be enhanced in the presence of EGF. Despite the toxicity of the inhibitor, levels of apoptosis induced by etoposide were only $5 \%$ higher with the inhibitor as compared with that of the control (28.7 and $33.6 \%$ ). Although EGF protection in the control samples was similar to that observed in Figure $6 \mathrm{~b}$ (reduction from 28.7 to $12.8 \%$ ), Erk inhibition completely reversed the protective effect conferred by EGF pre-treatment. In stark contrast to the control samples, co-treatment of etoposide with EGF in the presence of the Erk inhibitor showed higher levels of apoptosis compare with etoposide alone. These results indicate that $\mathrm{Mek} / \mathrm{Erk}$ signalling leads to increased Mcl-1 expression and has a critical role in the EGF survival response in breast cancer cells.

Activated Elk-1 correlates with increased levels of Mcl-1 in breast tumour samples

Knowledge of the molecular pathways governing Mcl-1 expression allows for the development of rationale therapeutic approaches; however, without clinically 

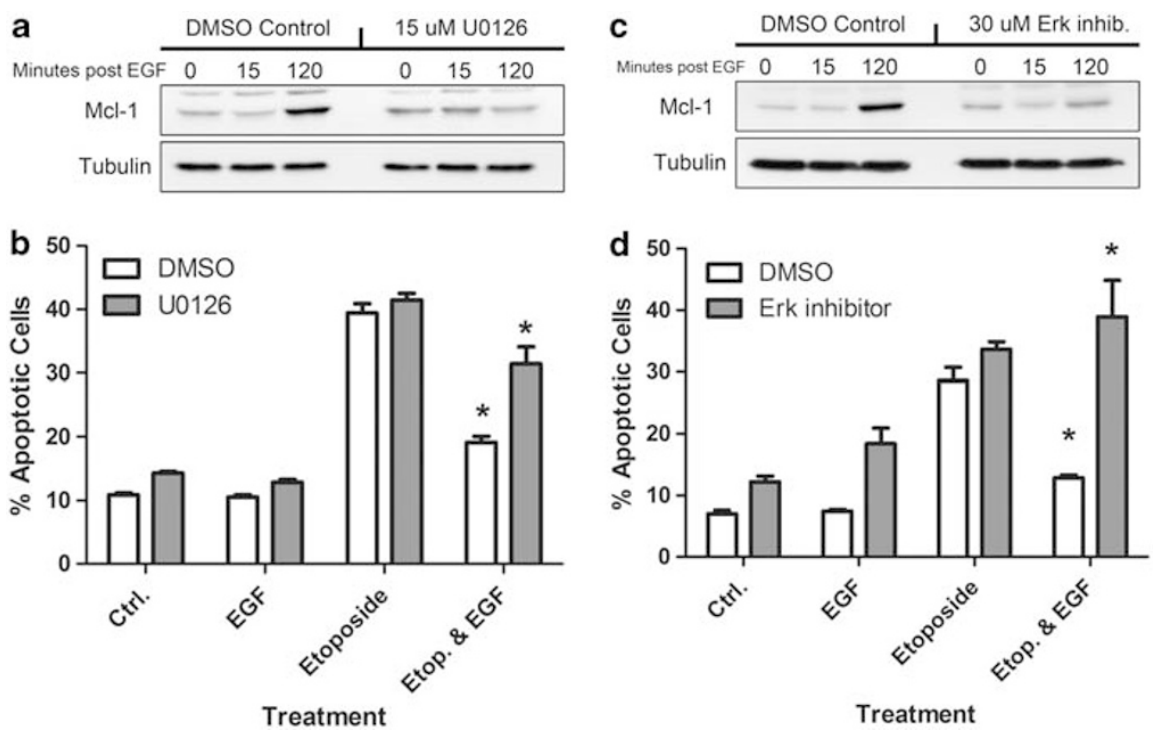

Figure 6 EGF protects breast cancer cells from apoptosis through a mechanism that relies on signalling via the Mek/Erk pathway. (a) SK-BR-3 cells were pre-treated with the Mek inhibitor U0126 at a concentration of $15 \mu \mathrm{m}$ for 20 min before addition of EGF. Mcl-1 protein levels were assessed by western blot following stimulation with EGF. (b) SK-BR-3 cells were pre-treated with the Mek inhibitor U0126 at a concentration of $15 \mu \mathrm{M}$ for $20 \mathrm{~min}$ before addition of EGF. One hour after treatment with EGF the cells were treated with etoposide at a concentration of $5 \mu \mathrm{m}$ for $18 \mathrm{~h}$. Apoptosis was assessed by analysis of the sub-G1 peak by flow cytometry. Data represents three independent experiments \pm standard error. (c) A similar experiment was performed as in (a) using the Erk inhibitor 3(2-aminoethyl)-5-((4-ethoxyphenyl)methylene)-2,4-thiazolidinedione. The cells were pre-treated for $20 \mathrm{~min}$ with the inhibitor at a concentration of $30 \mu \mathrm{m}$ before the addition of EGF. (d) As in (b) except cells were pre-treated with $20 \mu \mathrm{M}$ of the Erk inhibitor before addition of EGF. *indicates $P<0.05$.

relevant breast tumours the significance of these results will be diminished. To that end, we sought to determine if the signalling pathways regulating $\mathrm{Mcl}-1$ expression in the MCF-7 and SK-BR-3 cell lines are correlated to Mcl-1 expression in human breast tumour samples. Before proceeding to a large-scale analysis, a pilot study was performed with 26 breast tumour samples from the Manitoba Breast Tumour Bank. Tumour sections were stained for immunofluorescence with antibodies directed against Mcl-1 and phosphorylated Elk-1. Antibodies were pre-validated for immunofluorescence on tumour sections by overexpression and knockdown experiments in MCF-7 cells (Supplementary Figure 3A and B). A panel of 26 breast tumour sections were stained with antibodies against Mcl-1 and phospho-Elk-1 and scored using a $0-3$ point scoring system. In Supplementary Figure 4A, the data was analysed by plotting the scores as an XY scatter and performing a Spearman correlation test. We found a statistically significant positive correlation between phosphorylation of Elk-1 and Mcl-1 expression $\left(r_{S}=0.4303, P=0.0282\right)$ in the tested breast tumours. Representative images from the sampled tumours shown in Supplementary Figure 4b demonstrate that regions within an individual tissue section having high phospho-Elk-1 (green signal), also demonstrate strong staining for Mcl-1 (red signal). Conversely, regions with low phospho-Elk-1 levels tended to have corresponding low levels of Mcl-1.

Based upon the pilot study, we further investigated the relationship between activated Elk-1 and the expression level of Mcl-1 in a tissue microarray (TMA) provided by the Manitoba Breast Tumour Bank. The TMA consisted of 255 tumours that were previously assessed as ER $\alpha$ negative by a ligand binding assay. Each tumour was represented by two separate spots on the TMA. TMAs were immunostained with the Mcl-1 and phospho-Elk-1 antibodies previously demonstrated to be effective for immunofluorescence as well as antibodies directed against phospho-Erk1/2, ErbB1 and ErbB2. In Figures 7a and b, the tumours were separated into two groups based on the median Mcl-1 H-score of 120. Tumours with a Mcl-1 score of 120 or less were classified as 'low Mcl-1' and those with a score above the median were classified as 'high Mcl-1'. A MannWhitney test was performed to determine if the median phospho-Elk-1 and phospho-Erk1/2 scores (indicated by the solid horizontal line) were significantly different between the two groups. The median phospho-Elk-1 score for the low-Mcl-1 category was 75.0 and the median score for the high Mcl-1 score was 140, a difference that was statistically significant $(P<0.005)$. The median phospho-Erk1/2 scores were also significantly different with a score of 50.0 in the low-Mcl-1 subset and a score of 100.0 in the high subset. The phospho-Erk1/2 scores were also separated into two groups based on the median phospho-Elk-1 score. As Elk-1 is a substrate for Erk1/2 it was hypothesized that elevated levels of phospho-Erk1/2 would correlate with elevated levels of phospho-Elk-1. A significantly higher phospho-Erk1/2 score (150.0) was observed in tumours that demonstrated high levels of phospho-Elk-1 as compared with those that did not (50.0). In a similar manner the tumours were divided based on the median scores for ErbB1 and ErbB2. Increased expression of both receptors associated with a higher median Mcl-1 $\mathrm{H}$-score (Figures $7 \mathrm{~d}$ and e). This data supports the 

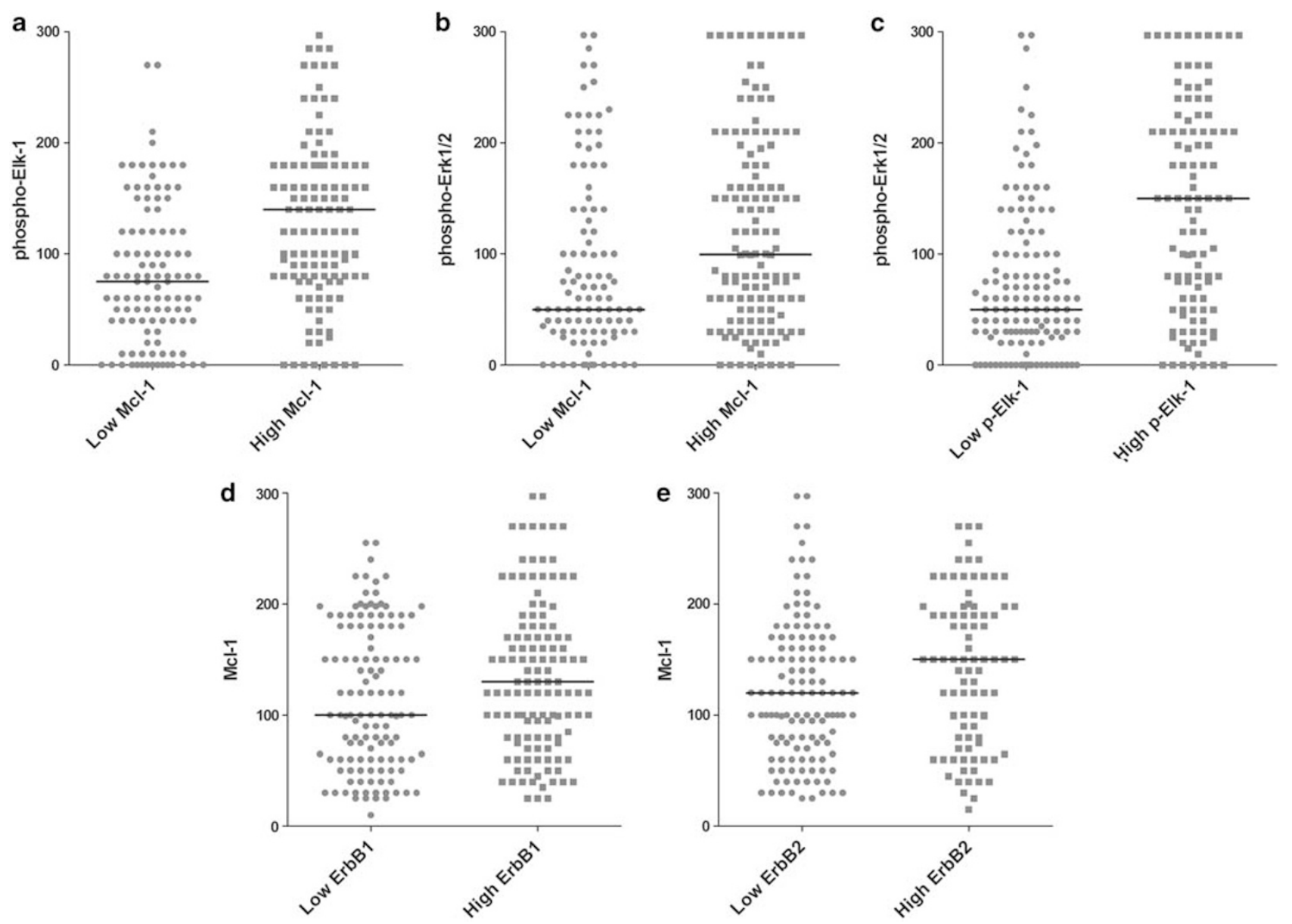

Figure 7 Activated Elk-1 correlates with increased levels of Mcl-1 in breast tumour samples. A TMA containing samples from 255 ER $\alpha$ negative breast tumours was stained by immunohistochemistry with antibodies specific for Elk-1 when phosphorylated at Ser383, Erk1/2 when phosphorylated at Thr202/Tyr204, ErbB1, ErbB2 and Mcl-1. TMAs were scored by two blinded independent observers. Tumours were assessed using the H-score method. An intensity score of 0-3 was multiplied by the percentage of tumour cells stained. Bars for all graphs represent median scores for each category. $P$-values were calculated by Mann-Whitney test. (a) $\mathrm{H}$-scores for phospho-Elk-1 were separated into two groups based on the median Mcl-1 H-score of 120. (b) H-scores for phospho-Erk1/2 were separated into two groups based on the median Mcl-1 H-score of 120 . (c) $\mathrm{H}$-scores for phospho-Erk1/2 were separated into two groups based on the median phospho-Elk-1 H-score of 100. (d) H-scores for Mcl-1 were separated into two groups based on the median ErbB1 $\mathrm{H}$-score of 85. (e) H-scores for Mcl-1 were separated into two groups based on the median ErbB2 H-score of 50.

regulation of Mcl-1 protein expression by EGF receptors through the Mek/Erk pathways mediated by Elk-1 activation within breast tumours.

\section{Discussion}

Mcl-1 is unique amongst the pro-survival Bcl-2 family members in the degree to which its expression is tightly regulated and the multiple levels at which this occurs (Akgul 2009). Besides having its expression being regulated at the transcriptional level, Mcl-1 also contains a PEST domain that confers a very short protein half-life due to degradation via the proteasome pathway (Akgul et al., 2000). This property allows for tight regulation of Mcl-1 and protein levels fluctuate rapidly in response to the changing extracellular environment. Another degree of regulation exists via alternative splicing to generate a smaller protein that is an activator of apoptosis (Bingle et al., 2000). Mcl-1 is also subjected to multiple post-translational modifications that include cleavage by caspases or enhancement of stability through phosphorylation (Le Gouill et al., 2004). Mcl-1 is further regulated by the mir-29b microRNA (Mott et al., 2007). These studies indicate that Mcl-1 is a dynamically regulated protein, and our results demonstrate that transcriptional control is an important aspect of Mcl-1 expression in breast cancer.

Overexpression or mutation of the EGF receptors is seen in a variety of tumour types (Klapper et al., 2000). In breast cancer, the EGF receptor ErbB2/Her-2 is overexpressed in $\sim 20 \%$ of cases (Nanda 2007; Singleton and Strickler 1992). The ErbB1 receptor is also increased in breast cancer but increased gene transcription rather than gene amplification appears to be the primary reason for overexpression (Chrysogelos and Dickson, 1994). In contrast to normal tissue the expression level of ErbB1 in breast cancer can be increased by as much as 20-fold (Herbst, 2004). 
Although less studied, ErbB3 is also found to be increased in $19-29 \%$ of breast cancer cases and this increase, like that of ErbB1, is not primarily due to a change in gene copy number (Sithanandam and Anderson, 2008). Although the prognostic significance of ErbB3 in breast cancer is not as straightforward as for Her-2, a general trend towards disease progression and poorer outcome is reported (Sithanandam and Anderson, 2008).

Therapeutics that target the EGF receptors ErbB1 and ErbB2 such as Herceptin and Lapatinib have successful clinical applications in breast cancer (Johnston et al., 2006). Despite these advances, resistance to treatments has been a recurring theme (Nahta and Esteva, 2006). We have previously shown a correlation between Her-2 overexpression and elevated Mcl-1 protein expression. We have also demonstrated that Mcl-1 can contribute to cell survival and resistance against Herceptin (Henson et al., 2006). In this study we confirmed the relationship between EGF signalling and upregulation of Mcl-1 and identified that the Mek/Erk signalling pathway, acting ultimately through activation of Elk-1, is critical in regulating Mcl-1 expression in breast cancer cells. We have also taken the results obtained in breast cancer cell lines and used them to make accurate predictions in breast tumour samples, supporting the clinical relevance of the study. Furthermore, we have determined that Mek/Erk signalling is essential for the survival advantage conferred by EGF in our cell line models. Over activation of any of the downstream components of this pathway could contribute to resistance to EGF receptor targeted therapies through an upregulation of Mcl-1.

It has previously been established that Mcl-1 is overexpressed in breast tumours and correlates with poor prognosis (Ding et al., 2007). In this study, we have demonstrated that Mcl-1 is a downstream target of activated EGF receptor signalling and that overexpression of Mcl-1 confers resistance to drug induced apoptosis. We have also demonstrated that a minimal expression level of Mcl-1 is critical for survival of the SK-BR-3 breast cancer cell line. This data indicate that Mcl-1 may be an important target for breast cancer treatment. Several in vitro studies have demonstrated effectiveness of Bcl-2 family inhibitors against breast cancer (Martin et al., 2009; Witters et al., 2007). The Bcl-2 inhibitor ABT-737 has shown effectiveness in breast cancer cells alone or in combination with EGF receptor inhibitors (Witters et al., 2007). ABT-737 resistant cells show increased Mcl-1 expression indicating that targeted Mcl-1 expression could be an effective treatment (Nguyen et al., 2007; Vogler et al., 2009).

We have shown that the transcription factor Elk-1 is an important regulator of $\mathrm{Mcl}-1$ expression. This supports studies describing Mcl-1 transcriptional regulation by tetradecanoylphorbol-13-acetate in HEK 293, HeLa and Ml-1 cell lines (Boros et al., 2009; Townsend et al., 1999; Vickers et al., 2004). Although we were able to validate the importance of Elk-1 in controlling Mcl-1 expression we found that knockdown of SRF had little or no effect on basal or induced Mcl-1 expression (Supplementary Figure 2) Whether this is due to insufficient knockdown, recruitment of other coactivators in the absence of SRF or Elk-1 acting independently is yet to be determined. Although many additional transcription factor binding sites were found within the Mcl-1 promoter such as Stat-3 and NF- $\mathrm{BB}$, two transcription factors that may have a role in Mcl-1 regulation in other cell types, it appears that these sites are not critical for the EGF induced regulation of Mcl-1 in these breast cancer cell lines (Boucher et al., 2000; Henson et al., 2006; Liu et al., 2003; Tsutsui et al., 2009). Furthermore, knockdown of both Stat-3 and NF-KB had no observable effect on basal or EGF induced Mcl1 protein levels (Supplementary Figure 2A). Taken together, this suggests that activation of Elk-1 is critical for upregulation of Mcl-1 expression at least in breast cancer cells.

The Mek/Erk signalling pathway has an important role in breast cancer progression (Sivaraman et al., 1997; Mueller et al., 2000). Although Ras mutations are infrequently observed in breast cancer, elevated activation of the protein is observed in a substantial proportion of tumours (Sivaraman et al., 1997; von Lintig et al., 2000). The basal-like subset of breast tumours has been identified as particularly susceptible to Mek inhibition (Mirzoeva et al., 2009). Furthermore, the Mek inhibitor PD0325901 has been found to be effective as a single agent as well as in combination with inhibitors of PI3K in murine xenograft models of basallike breast cancer (Hoeflich et al., 2009). Recently, the use of Mek inhibitors has demonstrated success in overcoming resistance to the EGF receptor inhibitor lapatinib (Sambade et al., 2009; Zoppoli et al., 2010). Our results point to the possibility that inhibitors of the Mek/Erk signalling cascade can be effective at blocking the expression of Mcl-1 in breast cancer. Our data also suggest that Mcl-1 is an important downstream mediator of the survival benefits conferred by overactivation of this signalling network. Inhibition of the transcription factor Elk-1 could be a further approach to block the overexpression of Mcl-1; however, small molecule inhibitors to Elk-1 are currently unavailable. Nevertheless, alterations in the Mcl-1 transcriptional regulation could be a viable strategy to sensitize breast cancer cells to EGF receptor inhibitors and Bcl-2 inhibitors.

\section{Materials and methods}

\section{Cell culture and reagents}

The human breast adenocarcinoma cell lines MCF-7 and SK-BR-3 were obtained from the American Type Culture Collection (ATCC, Manassas, VA, USA) in October of 2008 and December of 2009, respectively. Cell identity was confirmed by the ATCC by short tandem repeat analysis. Cells were maintained in a humidified $5 \% \mathrm{CO}_{2}$ incubator at $37^{\circ} \mathrm{C}$ and were passaged twice weekly. Cells were passaged no more than 20 times. MCF-7 cells were maintained in Dulbecco's modified Eagle's medium (Invitrogen, Burlington, ON Canada) supplemented with $10 \%$ fetal calf serum (Fisher Scientific, Pittsburgh PA, USA) and 100 units $/ \mathrm{ml}$ penicillin and $100 \mu \mathrm{g} / \mathrm{ml}$ streptomycin (Invitrogen). SK-BR-3 cells were 
maintained in McCoy's 5A medium (Invitrogen) with identical supplements. Recombinant human EGF was obtained from Sigma-Aldrich (Oakville, ON, Canada) and dissolved in $10 \mathrm{~mm}$ acetic acid with $0.1 \%$ bovine serum albumin. For all experiments, EGF was added to the media at a final concentration of $1 \mu \mathrm{g} / \mathrm{ml}$. Etoposide and doxorubicin (SigmaAldrich) were dissolved in dimethyl sulfoxide at a stock concentration of $50 \mathrm{~mm}$ and stored at $-20^{\circ} \mathrm{C}$. The MEK inhibitor U0126 (Promega, Madison, WI, USA) was dissolved in dimethyl sulfoxide at a concentration of $10 \mathrm{~mm}$ and stored at $-20{ }^{\circ} \mathrm{C}$. The Erk inhibitor 3-(2-aminoethyl)-5-((4-ethoxyphenyl) methylene)-2,4-thiazolidinedione (EMD Chemicals, Mississauga, ON, Canada) was dissolved in dimethyl sulfoxide at a concentration of $10 \mathrm{mg} / \mathrm{ml}$ and stored at $-20^{\circ} \mathrm{C}$. The following antibodies were used: rabbit anti-Mcl-1 (M8434 Sigma-Aldrich), rabbit anti-Elk-1 (ab32106 Abcam, Cambridge, MA, USA), mouse anti-SRF (MAB4369 Millipore, Billerica, MA, USA), rabbit anti-phospho-Elk-1 (Ser383) (9181, Cell Signaling, Boston, MA, USA), mouse antiphospho-P44/42 MAPK (Thr202/Tyr204) (9106, Cell Signaling), rabbit anti-P44/42 MAPK (9102, Cell Signaling), rabbit anti-NF- $\kappa$ B p65 (ab7970 Abcam), mouse anti- $\alpha$-tubulin (T6074 Sigma-Aldrich), rabbit-anti-Stat-3 (9132, Cell Signaling), rabbit anti-Her-2 (Dako, Mississauga, ON, Canada) and mouse anti-EGFR (Ventana, Tucson AZ, USA).

\section{Western blotting}

All whole-cell lysates were prepared with RIPA buffer $(50 \mathrm{~mm}$ Tris $\mathrm{pH} 8.0,150 \mathrm{~mm} \mathrm{NaCl}, 2 \mathrm{~mm}$ EDTA, $1 \%$ nonident P-40, $0.5 \%$ sodium deoxycholate, $0.1 \%$ SDS) supplemented with protease inhibitors (Complete mini, Roche, Laval, QC, Canada) and phosphatase inhibitors (phosphatase inhibitor cocktail 1 and 2, Sigma-Aldrich). Equal amounts of protein were resolved by SDS/polyacrylamide gel electrophoresis and transferred to polyvinyl difluoride membranes. Membranes were blocked in Tris buffered saline containing $0.1 \%$ Tween-20 (Tris-buffered saline Tween-20) and 5\% skim milk powder. Primary antibodies were incubated overnight at $4{ }^{\circ} \mathrm{C}$ in $5 \%$ milk Tris-buffered saline tween-20. Following incubation, membranes were washed threefold in Tris-buffered saline tween-20 and then incubated with the appropriate secondary antibody conjugated to horse radish peroxidise for 1 hour at room temperature in 5\% milk tris-buffered saline tween-20. Proteins were visualized on Hyperfilm ECL by enhanced chemiluminescence (GE Healthcare, Piscataway NJ, USA).

\section{$R N A$ isolation and real-time $(R T)-P C R$}

Total RNA was isolated using the Qiagen RNeasy Plus mini kit according to the manufacturer's protocol and RNA concentrations were quantified by measurement of absorbance at $260 \mathrm{~nm}$ with a spectraphotometer (SpectraMax M5, Molecular Devices, Sunnydale, CA, USA). In all $100 \mathrm{ng}$ total RNA was used as template for the real-time PCR. One-step RT-PCR was performed using the iScript One-step RT-PCR kit (Bio-Rad, Hercules, CA, USA) and cycling and data collection were performed on an iCycler thermal cycler (Bio-Rad) using the supplied software (iCycler IQ ver 3.1, Bio-Rad). The following primers specific to the Mcl-1 mRNA were used: forward: 5'-GCCAAGGACACAAAGCCA AT-3', reverse: 5'-AACTCCACAAACCCATCCCA-3'. The following primers specific to the housekeeping gene cyclophilin were used to standardize results: forward: 5'-GCTGCGT TCATTCCTTTG-3', reverse: 5'-CTCCTGGGTCTCTGCT TTG- $3^{\prime}$. The following cycling conditions were used: $50^{\circ} \mathrm{C}$ for $10 \mathrm{~min}$ followed by $95^{\circ} \mathrm{C}$ for $5 \mathrm{~min}$, then 40 cycles of $95^{\circ} \mathrm{C}$ for $10 \mathrm{~s}$ followed by $55^{\circ} \mathrm{C}$ for $30 \mathrm{~s}$ (data collection step). Primer specificity was confirmed by visualizing DNA on an agarose gel following PCR.

\section{Mcl-1 promoter constructs and luciferase assays}

The Mcl-1 promoter was amplified by PCR from a BAC clone containing the appropriate region of chromosome 1 (RP1154A4, Invitrogen). Primers were designed to amplify the $5^{\prime}$ promoter region $(3974 \mathrm{bp}$ downstream of the translation start site), as well as to generate seven large deletions from the $5^{\prime}$ end. Promoter fragments were cloned into the PGL3 luciferase reporter vector (Promega). A 7-bp deletions were introduced into the $3974 \mathrm{bp}$ fragment of the Mcl-1 promoter using the Quikchange II site directed mutagenesis kit according to the manufacturer's protocol (Stratagene, Santa Clara, CA, USA). The reporter constructs were transfected into MCF-7 and SK-BR-3 cells using GenePorter 2 transfection reagent (Genlantis, San Diego, CA, USA) along with a plasmid containing the $\beta$-galactosidase complementary DNA to standardize results. Twenty-four hours after transfection, the cells were serum starved for an additional $24 \mathrm{~h}$ and then treated with EGF or vehicle control. After $6 \mathrm{~h}$ treatment, cells were lysed in $200 \mu \mathrm{l}$ reporter lysis buffer (Promega) and luciferase activity was measured in $20 \mu 1$ lysate on an LMAX luminometer (Molecular devices) with $100 \mu$ l luciferase assay substrate (Promega). The $\beta$-galactosidase activity was assessed by combining $50 \mu \mathrm{l}$ lysate with $50 \mu \mathrm{l} 2 \mathrm{X} \beta$-gal buffer $(200 \mathrm{~mm}$ sodium phosphate $\mathrm{pH} 7.3,2 \mathrm{~mm} \mathrm{MgCl}_{2}, 100 \mathrm{~mm} \beta$-mercaptoethanol, $1.33 \mathrm{mg} / \mathrm{ml}$ ONPG) and measuring the absorbance at $450 \mathrm{~nm}$.

\section{ChIP}

ChIP was performed following EGF stimulation according a previously published protocol (Spencer et al., 2003). Following immunoprecipitation, and RNAse/proteinase $\mathrm{K}$ digestion of samples, ChIP DNA was isolated using the QiaQuick PCR purification kit (Qiagen, Mississauga, ON, Canada) and DNA concentration was determined using the PicoGreen dsDNA quantitation assay (Invitrogen). In all $0.1 \mathrm{ng}$ ChIP DNA was amplified by RT-PCR using primers specific to the Mcl-1 promoter (forward: 5'-TAGGTGCCGTGCGCAACCCT-3', reverse: 5'-ACTGGAAGGAAGCGGAAGTGAGAA-3') or the last exon of the $\mathrm{Mcl}-1$ gene (forward: $5^{\prime}$-TGTTGCTGGA GTAGGAGCTGGTTT-3', reverse: 5'-GCCATAATCCTC TTGCCACTTGCT-3'). To obtain fold enrichment values, the cT value of each ChIP sample was compared with the cT value of $0.1 \mathrm{ng}$ input DNA.

\section{Streptavidin pull-down assay}

To assess transcription factor binding to an $\mathrm{Mcl}-1$ promoter specific probe, a streptavidin pull-down assay was performed with biotin labelled probes specific to the Mcl-1 specific promoter. The probe sequence is as follows: 5'-CAACC CTCCGGAAGCTGCCGCCCCTTTCCCCTTTTATGGGA ATACTTTTT-3'. Following treatment with EGF for the indicated times, nuclear extraction was performed on $20 \times 10^{6}$ cells per time point. Nuclear extracts were pre-cleared with $50 \mu \mathrm{l}$ streptavidin agarose beads (Invitrogen) for $30 \mathrm{~min}$ at $4{ }^{\circ} \mathrm{C}$ with rotation. Following pre-clearance, a binding reaction was prepared that contained $500 \mu \mathrm{g}$ nuclear extract, $50 \mathrm{ng} / \mu \mathrm{l}$ poly dI-dC, $1 / 5$ volume $5 \times$ binding buffer $(50 \mathrm{~mm}$ Tris $\mathrm{pH} 7.5$, $250 \mathrm{~mm} \mathrm{KCl}, 5 \mathrm{~mm}$ dithiothreitol) and $100 \mathrm{~nm}$ biotin labelled probe. Binding reactions were incubated for $30 \mathrm{~min}$ at room temperature at which point $50 \mu \mathrm{l}$ streptavidin-agarose beads were added. Following a $30 \mathrm{~min}$ incubation, beads were spun down at 3000 r.p.m. for $1 \mathrm{~min}$ and washed $3 \times 5 \mathrm{~min}$ in phosphate-buffered saline. After washing, beads were resuspended in $50 \mu \mathrm{l} 2 \mathrm{X}$ SDS loading dye, boiled for $5 \mathrm{~min}$ and the 
isolated proteins were separated by SDS/polyacrylamide gel electrophoresis and western blot was performed to assess transcription factor binding.

\section{siRNA transfections}

The siRNA transfections were carried out using the Nucleofector (Amaxa, Walkersville, MD, USA) electroporation device according to the cell line specific protocols provided by the manufacturer. In all 30 pmol total siRNA was transfected per sample and all experiments were performed $48 \mathrm{~h}$ following transfection. Prevalidated siRNA duplexes were obtained from Invitrogen. The following siRNAs were used: Mcl- $1-5^{\prime}$-GAAAGUAUCACA GACGUUCUCGUAA-3', Elk-1-5'-GCGGCCAGAAGUUC GUCUACAAGUU-3', SRF-5'GCUACACGACCUUCAGC AAGAGGAA-3' Stat-3 - 5'GCAGUUUCUUCAGAGCAGG UAUCUU-3', NF- $\mathrm{B}$ B - sequence unavailable: product \#29410 (Santa Cruz Biotechnology, Santa Cruz, CA, USA).

\section{Assessment of apoptosis}

Analysis of apoptosis was performed by quantification of the sub-G1 peak by flow cytometry using a BD FACScalibur flow cytometer (BD Biosciences, Mississauga, ON, Canada) according to a previously published protocol (Riccardi and Nicoletti, 2006).

Immunostaining of paraffin embedded tissue sections and tumour microarrays

Tumour tissue sections were acquired from the Manitoba Breast Tumour Bank. Immunofluorescence was performed as previously published (Henson et al., 2006). Antibodies were validated by immunofluorescence performed on cells grown on coverslips with and without knockdown of the protein of interest by siRNA. TMAs were acquired from the Manitoba Breast Tumour Bank, operating under the approval of the Faculty of Medicine, University of Manitoba, Research Ethics Board (Watson et al., 1996). The details regarding TMA preparation and the protocol for immunohistochemistry staining and development has been described previously (Skliris et al., 2008). TMAs were scored using the H-score method by two blinded independent observers under the supervision of a pathologist at CancerCare Manitoba.

\section{Conflict of interest}

The authors declare no conflicts of interest.

\section{Acknowledgements}

The work is supported by a grant from the Canadian Breast Cancer Foundation, Prairie chapter. Evan Booy is supported by the Canadian Institutes for Health Research (CIHR) CGS Doctoral award. Dr Gibson is a Manitoba Research Chair. The Manitoba Tumour Bank is a member of the Canadian Tumour Repository Network (CTRNet) and is supported by a grant from the CIHR

\section{References}

Akgul C, Turner PC, White MR, Edwards SW. (2000). Functional analysis of the human Mcl-1 gene. Cell Mol Life Sci 57: 684-691.

Akgul C. (2009). Mcl-1 is a potential therapeutic target in multiple types of cancer. Cell Mol Life Sci 66: 1326-1336.

Backus HH, van Riel JM, van Groeningen CJ, Vos W, Dukers DF, Bloemena E et al. (2001). Rb, mcl-1 and p53 expression correlate with clinical outcome in patients with liver metastases from colorectal cancer. Ann Oncol 12: 779-785.

Bingle CD, Craig RW, Swales BM, Singleton V, Zhou P, Whyte MK. (2000). Exon skipping in Mcl-1 results in a bcl-2 homology domain 3 only gene product that promotes cell death. J Biol Chem 275: 22136-22146.

Boros J, O'Donnell A, Donaldson IJ, Kasza A, Zeef L, Sharrocks AD. (2009). Overlapping promoter targeting by Elk-1 and other divergent ETS-domain transcription factor family members. Nucleic Acids Res 37: 7368-7380.

Boucher MJ, Morisset J, Vachon PH, Reed JC, Laine J, Rivard N. (2000). MEK/ERK signaling pathway regulates the expression of $\mathrm{Bcl}-2$, Bcl-X(L), and $\mathrm{Mcl}-1$ and promotes survival of human pancreatic cancer cells. $J$ Cell Biochem 79: 355-369.

Cetin Z, Ozbilim G, Erdogan A, Luleci G, Karauzum SB. (2010). Evaluation of PTEN and Mcl-1 expressions in NSCLC expressing wild-type or mutated EGFR. Med Oncol 27: 853-860.

Chen F, Hancock CN, Macias AT, Joh J, Still K, Zhong S et al. (2006). Characterization of ATP-independent ERK inhibitors identified through in silico analysis of the active ERK2 structure. Bioorg Med Chem Lett 16: 6281-6287.

Chrysogelos SA, Dickson RB. (1994). EGF receptor expression, regulation, and function in breast cancer. Breast Cancer Res Treat 29: $29-40$.

Ding Q, He X, Xia W, Hsu JM, Chen CT, Li LY et al. (2007). Myeloid cell leukemia-1 inversely correlates with glycogen synthase kinase3 beta activity and associates with poor prognosis in human breast cancer. Cancer Res 67: 4564-4571.
Favata MF, Horiuchi KY, Manos EJ, Daulerio AJ, Stradley DA, Feeser WS et al. (1998). Identification of a novel inhibitor of mitogen-activated protein kinase kinase. $J$ Biol Chem 273: 18623-18632.

Heinemeyer T, Wingender E, Reuter I, Hermjakob H, Kel AE, Kel OV et al. (1998). Databases on transcriptional regulation: TRANSFAC, TRRD and COMPEL. Nucleic Acids Res 26: 362-367.

Henson ES, Hu X, Gibson SB. (2006). Herceptin sensitizes ErbB2overexpressing cells to apoptosis by reducing antiapoptotic Mcl-1 expression. Clin Cancer Res 12: 845-853.

Herbst RS. (2004). Review of epidermal growth factor receptor biology. Int J Radiat Oncol Biol Phys 59: 21-26.

Hoeflich KP, O'Brien C, Boyd Z, Cavet G, Guerrero S, Jung K et al. (2009). in vivo antitumor activity of MEK and phosphatidylinositol 3-kinase inhibitors in basal-like breast cancer models. Clin Cancer Res 15: 4649-4664.

Hsieh FC, Cheng G, Lin J. (2005). Evaluation of potential Stat3regulated genes in human breast cancer. Biochem Biophys Res Commun 335: 292-299.

Johnston JB, Navaratnam S, Pitz MW, Maniate JM, Wiechec E, Baust $\mathrm{H}$ et al. (2006). Targeting the EGFR pathway for cancer therapy. Curr Med Chem 13: 3483-3492.

Klapper LN, Kirschbaum MH, Sela M, Yarden Y. (2000). Biochemical and clinical implications of the ErbB/HER signaling network of growth factor receptors. Adv Cancer Res 77: 25-79.

Kuo ML, Chuang SE, Lin MT, Yang SY. (2001). The involvement of PI 3-K/Akt-dependent up-regulation of Mcl-1 in the prevention of apoptosis of Hep3B cells by interleukin-6. Oncogene 20: 677-685.

Le Gouill S, Podar K, Harousseau JL, Anderson KC. (2004). Mcl-1 regulation and its role in multiple myeloma. Cell Cycle 3: $1259-1262$.

Leu CM, Chang C, Hu C. (2000). Epidermal growth factor (EGF) suppresses staurosporine-induced apoptosis by inducing mcl-1 via 
the mitogen-activated protein kinase pathway. Oncogene 19: $1665-1675$.

Lin X, Morgan-Lappe S, Huang X, Li L, Zakula DM, Vernetti LA et al. (2007). 'Seed' analysis of off-target siRNAs reveals an essential role of Mcl-1 in resistance to the small-molecule Bcl-2/Bcl-XL inhibitor ABT-737. Oncogene 26: 3972-3979.

Liu H, Ma Y, Cole SM, Zander C, Chen KH, Karras J et al. (2003). Serine phosphorylation of STAT3 is essential for Mcl-1 expression and macrophage survival. Blood 102: 344-352.

Longo PG, Laurenti L, Gobessi S, Sica S, Leone G, Efremov DG. (2008). The Akt/Mcl-1 pathway plays a prominent role in mediating antiapoptotic signals downstream of the B-cell receptor in chronic lymphocytic leukemia B cells. Blood 111: 846-855.

Martin AP, Mitchell C, Rahmani M, Nephew KP, Grant S, Dent P. (2009). Inhibition of MCL-1 enhances lapatinib toxicity and overcomes lapatinib resistance via BAK-dependent autophagy. Cancer Biol Ther 8: 2084-2096.

Mirzoeva OK, Das D, Heiser LM, Bhattacharya S, Siwak D, Gendelman R et al. (2009). Basal subtype and MAPK/ERK kinase (MEK)-phosphoinositide 3-kinase feedback signaling determine susceptibility of breast cancer cells to MEK inhibition. Cancer Res 69: $565-572$.

Mott JL, Kobayashi S, Bronk SF, Gores GJ. (2007). mir-29 regulates Mcl-1 protein expression and apoptosis. Oncogene 26: 6133-6140.

Mueller H, Flury N, Eppenberger-Castori S, Kueng W, David F, Eppenberger U. (2000). Potential prognostic value of mitogenactivated protein kinase activity for disease-free survival of primary breast cancer patients. Int $J$ Cancer 89: 384-388.

Nahta R, Esteva FJ. (2006). HER2 therapy: molecular mechanisms of trastuzumab resistance. Breast Cancer Res 8: 215.

Nanda R. (2007). Targeting the human epidermal growth factor receptor 2 (HER2) in the treatment of breast cancer: recent advances and future directions. Rev Recent Clin Trials 2: $111-116$.

Nguyen M, Marcellus RC, Roulston A, Watson M, Serfass L, Murthy Madiraju SR et al. (2007). Small molecule obatoclax (GX15-070) antagonizes MCL-1 and overcomes MCL-1-mediated resistance to apoptosis. Proc Natl Acad Sci USA 104: 19512-19517.

Oltersdorf T, Elmore SW, Shoemaker AR, Armstrong RC, Augeri DJ, Belli BA et al. (2005). An inhibitor of Bcl-2 family proteins induces regression of solid tumours. Nature 435: 677-681.

Puthier D, Bataille R, Amiot M. (1999). IL-6 up-regulates mcl-1 in human myeloma cells through JAK/STAT rather than ras/MAP kinase pathway. Eur J Immunol 29: 3945-3950.

Riccardi C, Nicoletti I. (2006). Analysis of apoptosis by propidium iodide staining and flow cytometry. Nat Protoc 1: 1458-1461.

Sambade MJ, Camp JT, Kimple RJ, Sartor CI, Shields JM. (2009). Mechanism of lapatinib-mediated radiosensitization of breast cancer cells is primarily by inhibition of the Raf $>$ MEK $>$ ERK mitogen-activated protein kinase cascade and radiosensitization of lapatinib-resistant cells restored by direct inhibition of MEK. Radiother Oncol 93: 639-644.

Schubert KM, Duronio V. (2001). Distinct roles for extracellularsignal-regulated protein kinase (ERK) mitogen-activated protein kinases and phosphatidylinositol 3-kinase in the regulation of Mcl-1 synthesis. Biochem J 356: 473-480.

Schulze-Bergkamen H, Ehrenberg R, Hickmann L, Vick B, Urbanik T, Schimanski CC et al. (2008). Bcl-x(L) and myeloid cell leukaemia-1 contribute to apoptosis resistance of colorectal cancer cells. World $J$ Gastroenterol 14: 3829-3840.

Singleton TP, Strickler JG. (1992). Clinical and pathologic significance of the c-erbB-2 (HER-2/neu) oncogene. Pathol Annu 27(Part 1): $165-190$.

Sithanandam G, Anderson LM. (2008). The ERBB3 receptor in cancer and cancer gene therapy. Cancer Gene Ther 15: 413-448.
Sivaraman VS, Wang H, Nuovo GJ, Malbon CC. (1997). Hyperexpression of mitogen-activated protein kinase in human breast cancer. J Clin Invest 99: 1478-1483.

Skliris GP, Hube F, Gheorghiu I, Mutawe MM, Penner C, Watson PH et al. (2008). Expression of small breast epithelial mucin (SBEM) protein in tissue microarrays (TMAs) of primary invasive breast cancers. Histopathology 52: 355-369.

Song L, Coppola D, Livingston S, Cress D, Haura EB. (2005). Mcl-1 regulates survival and sensitivity to diverse apoptotic stimuli in human non-small cell lung cancer cells. Cancer Biol Ther 4: 267-276.

Spencer VA, Sun JM, Li L, Davie JR. (2003). Chromatin immunoprecipitation: a tool for studying histone acetylation and transcription factor binding. Methods 31: 67-75.

Townsend KJ, Zhou P, Qian L, Bieszczad CK, Lowrey CH, Yen A et al. (1999). Regulation of MCL1 through a serum response factor/ Elk-1-mediated mechanism links expression of a viability-promoting member of the BCL2 family to the induction of hematopoietic cell differentiation. J Biol Chem 274: 1801-1813.

Tse C, Shoemaker AR, Adickes J, Anderson MG, Chen J, Jin S et al. (2008). ABT-263: a potent and orally bioavailable Bcl-2 family inhibitor. Cancer Res 68: 3421-3428.

Tsutsui M, Yasuda H, Suto H, Imai H, Isobe Y, Sasaki M et al. (2009). Frequent STAT3 activation is associated with Mcl-1 expression in nasal NK-cell lymphoma. Int J Lab Hematol 32: 419-426.

van Delft MF, Wei AH, Mason KD, Vandenberg CJ, Chen L, Czabotar PE et al. (2006). The BH3 mimetic ABT-737 targets selective $\mathrm{Bcl}-2$ proteins and efficiently induces apoptosis via Bak/ Bax if Mcl-1 is neutralized. Cancer Cell 10: 389-399.

Vickers ER, Kasza A, Kurnaz IA, Seifert A, Zeef LA, O'Donnell A et al. (2004). Ternary complex factor-serum response factor complex-regulated gene activity is required for cellular proliferation and inhibition of apoptotic cell death. Mol Cell Biol 24: 10340-10351.

Vogler M, Dinsdale D, Dyer MJ, Cohen GM. (2009). Bcl-2 inhibitors: small molecules with a big impact on cancer therapy. Cell Death Differ 16: 360-367.

von Lintig FC, Dreilinger AD, Varki NM, Wallace AM, Casteel DE, Boss GR. (2000). Ras activation in human breast cancer. Breast Cancer Res Treat 62: 51-62.

Wang JM, Chao JR, Chen W, Kuo ML, Yen JJ, Yang-Yen HF. (1999). The antiapoptotic gene mcl-1 is up-regulated by the phosphatidylinositol 3-kinase/Akt signaling pathway through a transcription factor complex containing CREB. Mol Cell Biol 19: 6195-6206.

Watson PH, Snell L, Parisien M. (1996). The NCIC-Manitoba Breast Tumor Bank: a resource for applied cancer research. CMAJ 155: 281-283.

Witters LM, Witkoski A, Planas-Silva MD, Berger M, Viallet J, Lipton A. (2007). Synergistic inhibition of breast cancer cell lines with a dual inhibitor of EGFR-HER-2/neu and a Bcl-2 inhibitor. Oncol Rep 17: 465-469.

Yip KW, Reed JC. (2008). Bcl-2 family proteins and cancer. Oncogene 27: 6398-6406.

Yordy JS, Muise-Helmericks RC. (2000). Signal transduction and the Ets family of transcription factors. Oncogene 19: 6503-6513.

Zhang B, Gojo I, Fenton RG. (2002). Myeloid cell factor-1 is a critical survival factor for multiple myeloma. Blood 99: 1885-1893.

Zoppoli G, Moran E, Soncini D, Cea M, Garuti A, Rocco I et al. (2010). Ras-induced resistance to lapatinib is overcome by MEK inhibition. Curr Cancer Drug Targets 10: 168-175.

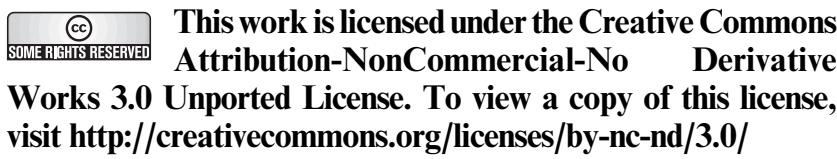

Supplementary Information accompanies the paper on the Oncogene website (http://www.nature.com/onc) 